\title{
Youth understanding of citizenship rights and responsibilities in Lesotho: Implications for civic education
}

\section{Mantsejoa Nthabiseng Thakaso and Julia Preece}

mahlonithakaso@gmail.com

Julia Preece (corresponding author) Preecej@ukzn.ac.za

http://orcid.org/0000-0002-3209-5935

University of KwaZulu-Natal

(Received 27 July 2017; accepted: 01 May 2018)

\section{Abstract}

This paper reports on findings from a recent $\mathrm{PhD}$ study that explored how young adults in Lesotho understood and applied their citizenship rights and responsibilities. It aims to inform proposed revisions to the 1995 Lesotho National Youth Policy that highlighted concerns that young adults are caught between the tensions of traditional values and their expectations of human rights that are internationally recognised and to which Lesotho is a signatory. The focus in this paper is on exploring the extent to which Basotho youth understood and behaved in relation to communitarian, civic republican, and cosmopolitan style citizenships. It also explores how and where youth learned their citizenship values with a view to recommending curriculum reform in the country's nonformal youth programmes. In this qualitative study youth from three different groups were interviewed and invited to provide and discuss photos of their citizenship activities. Recommendations included the need to develop a broader understanding of cosmopolitan and civic republican civic values and to include in a youth curriculum an opportunity to discuss intergenerational tensions that challenge how youth reconcile their human rights entitlements with traditional community responsibilities.

Keywords: citizenship curriculum; civic education; youth; Lesotho

\section{Introduction}

Young people in all countries are regarded as both a major human resource for development and key agents for social change, economic development, and technological innovation (United Nations, 2010). The United Nation's commitment to youth empowerment and participation has been reinforced by the Commonwealth (Commonwealth, 2013) and the United Nations Development Programme (UNDP, 2014). Since Africa is reported to be the youngest continent in the world (United Nations, 2010), this commitment is especially pertinent and is supported by the African Union Commission through its African Youth Charter (African Union Commission, 2006) which advocates that all African countries should 
generate a national youth policy and programme. It is further supported by the New Partnership for Africa's Development (NEPAD) that launched a youth desk that provided youth with a platform for dialogue that enabled them to contribute to policy debates (United Nations, 2010). This paper compares, briefly, youth policies in selected African countries with the Lesotho policy before discussing the literature on learning citizenship, three core traditions or practices for citizenship, current civic education practices in Lesotho, and citizenship curriculum content that is advocated in international civic education programmes. The empirical findings are then discussed in relation to the three citizenship practices, concluding with recommendations for a civic education curriculum for youth in Lesotho.

\section{Youth policies in Africa}

In line with the AUC recommendations there is evidence of youth policies across the continent. For example Kenya's policy was formulated in 2007, South Africa's in 2009, and Uganda's in 2004.

The policies of these three countries, Kenya, South Africa, and Uganda, clearly tabulate the rights of young people and also emphasise that these rights go hand in hand with responsibilities. For example, "the right to meaningful education" (Government of Kenya, GOK, 2007, pp. 5-6), and the "right to participation in making decisions that affect their lives" (Government of Uganda, GOU, 2004, p. 15), are aligned with responsibilities "to strengthen a culture of patriotic citizenship among young people and help them to become responsible adults who care for their families and others" (Republic of South Africa, RSA, 2009, p. 7). Both the Ugandan and Kenyan documents make reference to patriotism, loyalty, and the promotion of the well-being of their countries. South Africa, in particular, gives youth a right to partake fully in citizenship duties, including voting, decision-making processes and governance, and responsibility to "promote and advance their rights as they relate to themselves, other young people and fellow South Africans in general" (RSA, 2009, p. 19). These three policies share some similarities with the Lesotho National Youth Policy, which is discussed below.

\section{Lesotho}

Lesotho is classified as a low human developed country and ranks 161 out of 188 countries on the UNDP Human Development Index (UNDP, 2014a). Children and youth make up 63\% of the population and more than half of the population is under the age of 18 .

Compared with Kenya, South Africa, and Uganda, Lesotho's policy documents are old and pre-date many of the international new millennium statements.

\section{National Youth Policy of Lesotho (NYPL)}

The Ministry of Youth Gender, Sports and Recreation (MYGSR) produced a national youth policy in 1995 (Government of Lesotho, GOL, 1995). It includes the following statement. 
The youth should be perceived and serve as an instrument of social development. To this end, it should be aspired to having youth as good citizens, moulded by dynamic cultural and religious values, so that they can take their rightful place in society and fully participate in economic and socio-political development of peaceful Lesotho through individual and coherent group self-motivation. (GOL, 1995, p. 11)

This emphasises the nation's concern for good citizenship that is embedded in Lesotho's culture that advocates harmony and social cohesion. The policy recognises that young people experience problems that cause a conflict of expectations in Lesotho society since there is a generation gap between young people and adults. It states that "as a result young people are caught up in a struggle for power and authority as they strive to be independent in a society which treats them as dependents" (GOL, 1995, p. 7). The issue of youth being treated as dependents is not highlighted in the policies of the other three countries; this reflects a particular concern in Lesotho regarding its relationship to the principles of a modern democracy.

The Lesotho youth policy also has as one of its objectives a commitment to education,

ensuring that the type of education and training provided in the country is compatible with and responsive to the needs of the youth and, hence, of the nation as a whole. (GOL, 1995, p. 12)

The NYPL was intended to be a guiding document to define a course of action for young adults to bring about changes in society. Young adults are expected not only to adjust to these changes, but to meet, at the same time, their societal family expectations (GOL, 1995). The NYPL does not emphasise issues of rights and responsibilities in the same way as other national policies on the continent do. However, there are statements that implicitly refer to rights and responsibilities. The policy focus is on the issue of shifting values and traditions leading to cultural discontinuity (GOL, 1995). For instance, the document refers to a shift from the culture of disciplining a child through physical punishment to recognising that this form of discipline is now regarded as child abuse.

While the Lesotho policy document stresses the need to build on traditional cultural values, all three countries mentioned above have the common vision of empowering youth socially, politically, and economically to be productive and active citizens. This concurs with the agenda of international organisations. In the context of those policies the issue of rights and responsibilities and participation in public decision-making are highlighted. For example, in the Lesotho, Ugandan, and Kenyan policies, it is clearly elaborated that youth have a right to participate in making decisions that affect their lives. The Lesotho youth policy articulates this concern as "encouraging free and safe participation of all youth irrespective of gender in the conduct of public affairs and protection of law and order to motivate them and make them feel independent" (GOL, 1995, p. 14).

The NYPL stipulates that "youth organisations play an important role in the development of the young people to meet the demands made by society" (GOL,1995, p. 10). Youth in 
Lesotho become members of different clubs or organisations that are intended to help them address issues of concern to them. In this study, although one participant cohort was not selected on the basis of their membership of a specific organisation, it emerged that they all identified themselves as members of at least one organisation.

It is currently unclear whether youth are fully aware that their rights are also associated with responsibilities, duties, and/or obligations. Therefore, a deeper awareness of their understanding has a bearing on how civic education might be developed.

Although the NYPL is very dated, it is only now that revisions are being considered. In view of these current initiatives, the findings of this well-timed study could be used to inform a more up-to-date policy document and a strategic plan.

The following section focuses on how youth may learn about citizenship issues. Learning about citizenship may take place formally, informally, or in non-formal settings.

\section{Learning citizenship in a formal setting}

Formal education, according to Dib (1988), corresponds to a "systematic, organised model which is structured and administered according to a given set of laws and norms presenting a rather rigid curriculum" (p. 1). The Lesotho schools do provide a non-examinable Life Skills Education curriculum from primary to secondary level that currently reflects potential content that would be relevant to citizenship education. The Life Skills Education programme (GOL, 2007) general curriculum includes, among other things,

- enhancing good relations with one another and with communities;

- instilling good citizenship skills in learners; and

- enhancing learners' awareness of their rights and responsibilities as human beings. (p. vi)

The programme also addresses some core life skills which are intended to equip youth with skills in decision making and problem solving, creative thinking, empathy, assertiveness, and self-esteem (GOL, 2007). However, this curriculum is addressed minimally because schools concentrate on examinable subjects (Thakaso, 2010).

\section{Learning citizenship in an informal setting}

Delanty (2003) attests that learning about citizenship occurs mostly in the informal context of people's everyday lives and that it is also heavily influenced by critical and formative events in their lives. In other words, the process of citizenship learning is ongoing throughout one's life.

Jarvis (2008) also points out that the European Commission acknowledged that "citizenship could not be taught [formally] since it had cognitive, affective and practical dimensions" (p. 203). This statement concurs with Delanty's point in implying that it is a process that arises 
from daily experience. This suggests that citizenship education programmes must provide practical opportunities for learning through doing.

The family has been identified as the key institution for young people to learn about their own citizenship status and this is referred to as a source of informal learning. In Lesotho, young people first learn about their cultural morals, values, and norms in the family setting.

\section{Learning citizenship in a non-formal setting}

Coombs and Ahmed (1974) define non-formal education as "any organised educational activity carried on outside the framework of the formal system to provide selected types of learning to particular sub groups in the population, adults as well as children" (p. 8). Youth organisations are a potential source of non-formal education and learning. The potential for youth organisations in Lesotho to address these issues needs further exploration.

\section{Curriculum for civic education programmes}

According to the Lesotho's Independent Electoral Commission Manual (2006), civic education is the means by which the public is equipped with skills to participate actively in public decision-making and influence this process. However, Ngozwana (2014) reveals that public civic education programmes in the country tend to concentrate on the technical aspects of registering and how to vote in general elections. A brief review of selected literature on civic education programmes is therefore necessary to provide a basis for understanding what may be required in the Lesotho context.

There is a very fine distinguishing line, if at all, between civic and citizenship education, so the two terms are used interchangeably. Although Sigauke (2012) argues that citizenship "is subjected to a diversity of meanings and interpretations" (p. 215), Fitzpatrick (2006) contends that civic education has no specific definition, so he chooses to understand it purely as "that which helps to make a man [sic] a useful citizen" (p. 278). Piattoeva (2005) explains that the aim of citizenship education is to connect citizens to their states and nations and make them aware of their roles, rights, and duties in their countries. Etzioni (1996), as cited by Dahal (2002), claims that civic education's primary concern is to create a civic culture which is committed to broadening and deepening democracy in both the public and private lives of citizens. Civic education should, therefore, be planned and structured in a way that promotes democracy, enhances human skills, and promotes opportunities to question the status quo (Ngozwana, 2014).

In recognition of the importance of education for citizenship, Oxfam (2006) developed a Curriculum for Global Citizenship that has key elements for developing the kind of ideal envisioned citizen. These are identified as knowledge and understanding that includes "globalisation and interdependence" (p. 8), skills encompassing critical thinking, and the ability to argue effectively. Citing Crick (1998, pp. 11-13) at some length, Biesta and Lawy (2006) suggest three key elements for citizen education. 
Firstly, social and moral responsibility: 'children learning from the very beginning self-confidence and socially and morally responsible behaviour both in and beyond the classroom, both towards those in authority and towards each other.' . .

Secondly, community involvement: 'learning about and becoming helpfully involved in the life and concerns of their communities, including learning through community involvement and service to the community.' ...

Thirdly, political literacy: 'pupils learning about and how to make themselves effective in public life through knowledge, skills and values.' (p. 71)

These key elements are intended to mould youth to become responsible citizens. Through this education process they are expected to become politically literate and effective citizens. It should be noted that, apart from Oxfam's, the emphasis in these programmes is on nurturing responsibility rather than challenging the status quo.

Against the fixed rule-learning model outlined above, Delanty (2003) encourages moving to a dynamic view of citizenship that addresses the development processes of learning in different contexts. This conception of learning may be more relevant to the Lesotho context because youth are most likely to be learning about citizenship through participation in their youth groups.

This study explored the extent to which Basotho youth learned about citizenship in terms of their rights and responsibilities, but before turning to the empirical study it is necessary to explore briefly some core concepts that help to define the nature of citizenship and its enactment.

\section{Citizenship as a theoretical concept}

Citizenship is widely recognised as a complex idea which has historical roots and which has evolved over time (see, for example, Bachmann and Staerkle, 2000). It has legal and social status but also reflects behavior in terms of participation in and contribution to public life (Yuval-Davis, 2006). In this paper the focus is on how young Basotho youth interpret their rights and responsibilities as contributions to public life. In respect of responsibilities Delanty (2000), among others, discusses three theoretical traditions of citizenship: the communitarian, the civic republican, and the cosmopolitan. Although there are overlaps between and among these three concepts, they can be distinguished.

- Communitarianism is associated with volunteering and caring within a local community; it functions generally within a defined geographical space. Volunteering as an element of communitarianism is considered to be the heart of community building (International Federation of Red Cross \& Red Crescent Societies (IFRC), 2011). Hall and Coffey (2007) see volunteering and community development as the bread and butter of communitarian citizenship. It satisfies the person doing the act as well as the receiver, thereby promoting harmonious relations in communities. 
Communitarian citizenship in African contexts is associated with the South African word ubuntu, a concept that embraces the communitarian values of trust, unity, and sharing, core features that manifest the philosophy of the co-existence of Africans (Waghid, 2014). Communitarianism can perhaps be summed up in the Lesotho concept of being a good citizen; it is unlikely to challenge the status quo.

- Civic republicanism is associated with working collectively in an organisation of shared interests to address a particular issue. According to Harber and Mncube (2012), this usually involves people who form themselves into civic groups for the common purpose of raising awareness about issues of concern. People engage collectively and actively in dialogue and debates to allow constructive and fair decision making. This form of citizenship often can be interpreted as active citizenship and has the potential to challenge the status quo or disrupt social harmony in the name of social justice or conscientisation.

- Cosmopolitanism is concerned with working with others on an international or global scale to address issues of international concern. Cosmopolitan citizens see themselves generally as part of a global network and therefore often extend civic republican citizenship goals and values into global movements. Their view of citizenship is to encourage the recognition of our common humanity and solidarity with others but also often to address injustices. Cosmopolitanism, when achieved, allows people an opportunity to affect the lives of others everywhere and to learn from each other, thus increasing the exchange of ideas among the nations of the world. Gauntlet (2011) argues that this increases engagement and connection with social and physical environments.

Since the concepts of rights and responsibilities in Lesotho are a source of tension, it is worth analysing briefly how the literature reflects on these terms.

\section{Citizenship rights}

Rights are defined by Kelly (1995) as a legal term that allows people to perform certain acts supported by the legal system within a specific society. Isin and Turner (2007) define human rights as "rights enjoyed by individuals by virtue of being human and as a consequence of their shared vulnerability" (p. 12). These two definitions highlight the notion of freedom afforded to individuals within a society and the need for this to be respected. UNICEF CA. (2009) suggests that "as global citizens children and young people must learn to exercise their rights responsibly as part of their duties of citizenship" (p. 1).

Bosl and Diescho (2009) indicate that despite its importance, the concept of human rights arrived late in Africa. Indeed, culturally, Basotho still see their offspring as children irrespective of age or marital status (Ngozwana, 2014). In contemporary Lesotho, this causes tensions between parents and children because parents believe children misbehave as a result of claiming that they have rights (Ngozwana, 2014). This stereotyped perception of young people by their parents as being immature is noted not only in Lesotho but is also acknowledged in the report by Innovations in Civic Participation (ICP) and Pravah (2009) 
that states that "parental attitudes work against young people taking leadership or pursuing ideas in which they are interested" (p. 23). Nevertheless, The Human Rights Resource Centre (HRRC, 1999) in Minnesota, among others, reiterates the importance of educating youth about their rights since this ensures human dignity for all and is a step towards curbing social ills. It is therefore imperative that a civic education curriculum address the concept of rights with responsibilities.

\section{Citizenship responsibility}

Responsibility is defined by the Concise Oxford Dictionary (2004) as "an opportunity or ability to act independently and take decisions without authorization." Waghid (2014) interprets being responsible in terms of an individual's possessing the capacity to respond or to do something about a situation, or the ability or power to change that situation. The Human Rights Resource Centre (HRRC, 1999) suggests that young people can exercise their responsibilities as citizens to create awareness and conscientise those with whom they interact. This suggests that a sense of responsibility empowers them to bring change to their communities, and is in accordance with Article 27 of the African Charter on Human and People's Rights that states that, "every individual shall have duties towards his family and society, the state and other legally recognised communities and the international community" (Organisation of African Unity, OAU, 1981, p. 8). Preece and Mosweunyane (2004) suggest that responsibility is an attitude that people learn according to the environment in which they live, thus indicating that a person becomes aware of his or her own responsibility in context. In view of the age of the young people in the study it is most likely that there were some responsibilities that they were expected to carry out which they had learned as they were growing up.

\section{Methodology}

This study adopted an interpretivist paradigm that, following Blanche and Durrheim (2006) allowed for the interpretation of young people's perceptions and their understandings of citizenship in terms of subjective reasons and meaning making. The data that informs this paper was generated in the Roma Valley of Lesotho during 2016.

In line with Rule and John (2011), the study employed a qualitative case study approach, using Focus Group Discussions (FGD) followed by photovoice to collect data from youth in three case studies. The participants were members of a religious youth group, Lesotho Youth Christian Movement (LYCM); members of a political youth group of students at university, Lesotho Students Convention (LESCO); and a Mixed Social Group (MSG) who were members of different groups, mostly completing their high school and not employed. All these groups were from the Roma Valley and the rationale for choosing them was based on three key contexts for youth participation and sharing. First, religion plays a vital role in the lives of Basotho (Morojele, 2009) and therefore the notion of God has a strong influence on Basotho lives. Second, politics is a key domain for citizenship activity and it was important to 
include a politically oriented social group. Third, youth meet because of a shared interest in a particular activity or skill such as music or drama.

The selection of participants for LYCM and LESCO was based on convenience sampling and ensured an equal participation of males and females. After a meeting during which the study was explained to each organization, the leaders of each group were invited to provide ten volunteers for the study. The snowball method was used for the third group-two individuals known to the researcher (the first author of this paper) were asked to supply volunteers whom she knew personally. The FGD method, (see Kelly, 2006) was chosen so that young people would be enabled to share and bounce ideas off each other. Photovoice was a follow-up strategy that enabled the young people to explain through photos events in which they took part, and how and why they engaged in citizenship activities. One of the key precepts of photovoice is that participants' "messages—both explicit and hidden-help to shape our concepts of what is real and what is normal" (Wang, 1999, p. 186). This method allowed the young people to take pictures that they felt reflected their citizenship behaviour and gave them the opportunity to talk about the pictures in a follow-up group discussion. They were also asked to explain what they saw as significant in the pictures in relation to their citizenship behaviour, rights, and responsibilities.

Although the initial intention was to obtain groups of 10 for the FGDs and follow-up photovoice sessions a total of 25 youth participated in the study, 7 from LESCO and 8 from the MSG. They were between the ages of 18 and 30 and are referred to as youth according to the Lesotho youth policy. The pseudonyms of speakers are coded M (male) or F (female).

Data was first analysed inductively by identifying relevant themes emerging from the data. This entailed reading and re-reading the data to look for response patterns. Those themes were later deductively analysed to relate them to the theories of the study and, following Blanche and Durrhiem (2006), this provided a means for illustrating the participants' subjective understanding of their world.

\section{Findings}

Although citizenship has many meanings and aspects such as identity, and legal status, the findings in this paper focus on how young adults understood and learned about their citizenship rights and responsibilities in contemporary Lesotho because these issues are the most relevant for a non-formal civic education programme that would contribute to a revised youth policy.

\section{Understanding citizenship as responsibility}

The most common way that youth demonstrated their understanding of citizenship behaviour could be illustrated as communitarianism. Most of the participants felt they had a responsibility, as citizens, to give something back to their country. For instance Matsieng (M) 
from LESCO had the confidence that as a Mosotho, he belonged to the whole country and its laws, and had a responsibility to effect change in Lesotho.

I feel like being a citizen means a lot ... I am a part of the whole system and I feel like I matter in everything, I have the ability to make change and I love my country and I believe that things can change any time if I work harder for my country.

\section{Communitarianism}

According to Nyamnjoh (2002), African people are expected to invest in their home village (and country) as the best insurance policy and the ultimate sign of success. When young people leave their home villages it is important that they continue to invest in these communities through activities that maintain their home links, so that if/when they rejoin their communities they will be accepted and acknowledged for having done good deeds. During the discussions participants identified commitments that reflected a sense of citizenship responsibility towards their community's development. They used their photographs to illustrate how they had invested in their communities. These actions are an indication that the youth group members had retained a communitarian sense of responsibility towards their rural societies. For example, the LCYM group discussed their visit to a bereaved family in one of the remote villages of the Roma Valley. In the photovoice session, Big mama (F) said,

One of us had lost her mother so we had gone there to help and when we arrived there, we found only the elderly and we felt we had to prepare some food for them before we left.

There was evidence of similar acts of responsibility in the form of communitarianism in the other groups. Some MSG members made it their responsibility to provide clothing for the vulnerable children and others in the Roma Valley. Mapsy (F) explained this exercise.

We also wanted to show other people [in the church] that if you have something that you don't like anymore there are some people who are needy, so that they could see how others could benefit from such things.

This exercise was carried out with the assistance of the village committees, whose members were requested to provide lists of orphaned and vulnerable children in the communities. The nature of these activities reflects similar examples and attitudes to those articulated by, for example, Preece and Mosweunyane (2004). They share Ngozwana's (2014) argument that "a citizen earns a right of citizenship through their participation in society, by attending to duties and responsibilities" (p. 62).

Waghid (2014) stipulates that such communal sharing with one's community is determined by the individual's sense of responsibility or ubuntu towards the group and the group's responsibility towards the individual. For example, the elderly, destitute, and helpless are expected to be prime recipients of ubuntu. The youth considered caring for the elderly an 
important aspect and feature of good citizenship. President (M) from LESCO, during the FGD, elaborated on this.

We had a function at the Netherlands Hall where we [were] advocating for the rights of the old people ... if you look at countries like Britain and the U.S. there are social security facilities, free transport ... but in our country we have nothing . . . so that means we as young people we owe these people, we felt we have to pay ... [give back to community].

Communitarianism as volunteering could also, however, be motivated by a desire to promote change. This was particularly evident in the more politically motivated and aware LESCO group from the university. During a visit to Mafeteng in the south of the country, LESCO members worked together to assist the people who were hoeing the fields. These young people stated that they wanted to promote self reliance within their communities. as Topino (F) explained,

We encouraged the farmers we interacted with to become more self reliant. As Basotho create your own jobs so that you can be assisted to reach your dreams.

The LESCO group discouraged the community members who were working in their fields from depending solely on handouts from the government, encouraging them, rather, to seek solutions to their own identified needs. They encouraged them to continue working so that they would reap better produce. Ralichelete (M) explained,

As they do [did] this they were creating better lives for themselves so that in future they don't starve.

There was a sense, therefore, that the LESCO members had moved from seeing citizenship responsibility as purely benevolent care or charity work, to one that would impact on people's thinking. Giving back to the community now also meant educating the community to think differently about their situation. Waghid (2014) reminds us that ubuntu not only involves being empathetic, but "one actually responds to the person by evoking his or her potentialities in order that he or she does something about altering and modifying his or her condition of vulnerability" (p. 61). This can be interpreted to mean that the responsible citizen not only provides for others but builds capacity in them to develop their own self sufficiency. This aspect of communitarianism was also evident in other participants. Dan (M) from the MSG group said that his theatre club hosted plays for the small children at local primary schools or in the communities, providing both a fun-filled and educative role for the audience.

We entertain small children through drama because we know they get clothes and food [from other groups] so we just visit them to do things differently and have fun with them. Most of our messages are on HIV/AIDS, teenage pregnancy, alcohol and drug abuse because we feel they are most appropriate to the youth. 
These findings showed that in spite of the intergenerational concerns articulated in Ngozwana's (2014) study, youth who were members of specific organisations did indeed contribute to their community's needs as volunteers, thus following the communitarian tradition of their culture.

Communitarianism, however, is only one form of citizenship. This study also sought out other forms of contribution that the youth chose to make to address the wider political or social needs of their society such as injustices or inequalities. LESCO members, to a greater extent than the other two groups, showed a combination of communitarianism and civic republicanism. In other words, they employed their own Afrocentric notion of civic republicanism, which combined communitarian values of bonding and building links with communities with the political aim of educating them about their rights. Put another way, civic republicanism takes on a communitarian role because the notion of collectiveness is the way that African communities engage with each other. This combined role has implications for how civic education should be taught and enables youth to see how to merge the traditional value system with a more proactive, educative stand. The concept of ubuntu serves to bridge these two notions of citizenship.

\section{Civic republicanism}

Civic republicanism puts emphasis on the role of civil society as an organised group of people who interact with state and society or community. Here, citizenship participation is often more political, but it still includes collective action towards common goals (Harber \& Mncube, 2012). Although there were few examples of this kind of citizenship across the three youth groups, the LESCO group provided one example of how they saw themselves as having a political sensitisation role towards their communities. They joined community members working on road construction with a view to engaging in conversation to educate them about their civic rights as electors as they worked.

Comrade (M) explained that these people were not aware of their political right to vote for someone who would bring about infrastructural development in the communities. During the discussions villagers indicated that they did not have roads because they had not previously voted for the current Member of Parliament who was punishing them for not voting for him because he belonged to a different party. The LESCO group's mission was to lobby for political party representation of reliable people who would be accountable to their communities since the current representatives were uncooperative when they knew that people had not voted for them. Comrade reiterated,

But because we are now here let us change and give someone your votes who cares. Stop giving them to someone who had made himself a mortal god in that area, knowing that everything is for himself.

This implies that civic republicanism is potentially threatening to traditional communitarian societies because it allows for an element of confrontation towards the government by the people. Nevertheless, the ideology of the civic republican intervention could develop the 
required level of critical thinking that the village communities require to make government address their needs. There is the potential for developing a civic republican citizenship by building on people's knowledge and frustration about their government and this could be a platform from which to encourage civic responsibility in the form of political awarenessraising.

\section{Citizenship as cosmopolitanism}

Cosmopolitan citizens have been referred to as global citizens or citizens of the world. As an enclave within South Africa, Lesotho is distanced from other national border relations and there are indications that many parts of Lesotho are marginalised from the global world (Preece, 2009). Nevertheless, in the context of wider global relations, it is important to see to what extent the youth in this study saw themselves as part of global citizenship movements.

Although the concept of citizenship as an active role within the wider world was not clearly understood by all participants in this study, the findings revealed that some youth articulated values that reflected the concept of cosmopolitanism. For example, Comrade from LESCO explained he would regularly attempt to use different media sources to keep up to date with news around the world.

First thing I do is to turn on my radio and listen [to] what is happening around the world and take my phone to get to the social networks. I also read newspapers.

UNESCO (2015) indicates that globally more than 90\% of young people between 18 and 24 are on some form of social media. This suggests that there is a growing trend for youth to engage globally to become part of what is going on. Delanty (2000), among others, contends that cosmopolitan citizens do not belong to one particular nation; cosmopolitan citizenship is an opportunity to connect through globalization networks and other means which go beyond the nation state's boundaries. According to President (M) from LESCO group, consciousness about what is happening globally can have a positive or negative impact on the country of Lesotho. He argued,

As a nation we have the world [which] is now [a global] village so if we can know what is happening outside your own state ... they may come and help you in your state so you have to be aware ... we have to be alert to the good or bad that is happening around the world.

There were few examples of cosmopolitan citizenship values from the other youth groups. However, they did demonstrate participation in international competitions. The above examples of interest in world affairs and in engaging internationally are tentative indicators of this transition from civic republicanism to cosmopolitan citizenship.

Endresen (2009) stipulates that citizenship is inclusive of a set of rights which people as citizens can employ in society. The youth's understandings of those rights are discussed in the next section. 


\section{Learning and understanding citizenship rights}

Elechi (2004) stipulates that human rights are a cultural and value laden concept to which a person is entitled for no special reason other than being human. It was evident that because of cultural tradition and beliefs parents were not comfortable talking about rights to their children. The young people's responses, supported by previous studies (Ngozwana, 2014), indicate that parents felt that the international position on rights as a concept meant that children were given too much freedom; at the same time, children felt that their parents were denying them their rights. These observations suggest the youths' awareness of a generational issue regarding understanding this concept. They were keen to bridge that gap and were also keen to address these differences in a less confrontational way with their own children. Tempest (M) explained,

Our parents grew up not being taught about them [rights], they brought us up without talking about them, so for us they are only coming up now and maybe we will also be able to pass them on/educate our children about them.

Youth in Lesotho seemed to haphazardly learn about their rights from school and different organisations that they join. Tempest (M) from LCYM indicated,

If you are a Mosotho there is nowhere parents sit you down and educate you about your rights.

Princess (F) from LCYM highlighted that she learned about human rights only from outside the family.

At tertiary level, there was a programme on human rights and that is where I learned about them.

The MSG, during their meeting, seemed to be confused regarding interpretations of rights and responsibilities. This confusion may have been a result of exposure to different schooling and to an individual's background. Mapsy (F) perceived a right as someone's responsibility towards her.

A right is a responsibility due to me ... it is someone's responsibility ... after you have been given a right then you have a responsibility over it. Your parent has a responsibility to take you to school; you have a right and responsibility to study.

Views from all three groups indicated that youth were not being allowed to use their rights. According to Princess (F), they had not been given a chance to exercise their rights and responsibilities.

Ha rea tloaetsoa ho nka boikarabello ba rona (we have not been made used to taking our responsibilities) ... a as most of the time we are referred to as children. If you want to do something they will always say go away, you are still a child you don't know anything and that discourages us. 
Princess (F) made a further point.

They [parents] will not tabulate your rights [but] one will say I will buy you a dress.

This implies that parents know it is the child's right to receive clothes from them, but it is not necessarily a shared decision. A lack of understanding about rights between parents and children in Lesotho can be deduced from Princess's statement and this is further alluded to by Dan from MSG.

I do not think we understand each other about rights. Like now I am a President of Mankabelane in the campus theatre group and am expected to ensure that group ... but I do not know my rights to ensure that it grows.

Therefore, it is not easy for youth in Lesotho to even claim their rights from their parents. The common understanding is that rights are a generational and not a cultural phenomenon because the older generation does not recognise the concept of rights in the same way as the younger one does. Since the inception of these rights, there is even a common saying in the Sesotho culture that modern children are bana ba litokelo (children of rights), that refers to them as no longer controllable by their elders and a sign that the Basotho culture is being ignored. It was noted that the new generation seemed to have a different view and was bringing in a new discourse about children; they were children of rights who by implication did not belong to their parents in the same way as their parents did to theirs.

There was a sense that parents could not teach children about something they themselves did not know about or understand. The concept of rights was mostly learned at school or at tertiary institutions through interaction with peers and from their youth organisations.

This lack of awareness was evident in a number of discussions. Although the NYPL (1995) highlighted this issue more than 20 years ago, the challenge of understanding is still that the notion of rights needs further exploration at an educational level and should also be related to responsibilities.

\section{Conclusions and recommendations}

The findings in this study suggest that membership of youth groups enabled the participants to undertake a range of communitarian citizenship responsibilities. But their limited involvement in civic republican or cosmopolitan citizenship activities may, at least partially, reflect their less conscious understanding of the importance of rights as a lever for social justice and change in society. Although a formal curriculum is available it is taught sparingly, if at all. Furthermore, as the literature has pointed out (see Delanty, 2000; Jarvis, 2007) learning about citizenship is a lifelong process and better learned through practical action. In this respect, those participants who had been exposed at university to learning about citizenship rights were better placed to articulate and promote those rights in their communities. 
There is also evidence that while recognising international programmes such as those promoted by Oxfam that encourage critical thinking and the ability to change, and the British programme advocated by Crick (1998) as cited by Biesta \& Lawy (2006), which emphasises the role of responsible citizenship to be effective in public life, the context-specific situation of Lesotho requires a context-specific programme that directly addresses the intergenerational issues of rights and culture. The suggestion by Waghid (2014) that the concept of ubuntu has potential to provide an African perspective on the notion of our common commitment to each other and to promote change may be offered as a contribution to this challenge. It might be further noted that the more recent youth policies of other African governments place more explicit emphasis on rights and responsibilities, including the right of youth to participate in decisions affecting their lives. These differences of focus could perhaps be incorporated into the revised Lesotho youth policy in a way that enables a youth curriculum to be developed in tertiary educational contexts as well as in non-formal groups outside of school.

\section{References}

African Union Commission. (2006). African youth charter. Retrieved from www.auc.org

Bachmann, C., \& Staerkle, C. (2000). The meanings of citizenship: From status to social process. Retrieved from https://www.yumpu.com/en/document/view/11369993/2-themeanings-of-citizenship-from-status-to-social-process-cimera

Biesta, G., \& Lawy, R. (2006). From teaching citizenship to learning democracy: Overcoming individualism in research policy and practice. Cambridge Journal of Education, 36(1), 63-79.

Blanche, M. T., \& Durrheim, K. (2006). Histories of the present: Social science research in context. In M. T. Blanche, K. Durrheim, \& D. Painter (Eds.), Research in practice: Applied methods for the social sciences (pp. 1-17). Cape Town, South Africa: UCT Press.

Bosl, A., \& Diescho, J. (Eds.). (2009). Introduction. In A. Bosl \& J. Diescho (Eds.), Human rights in Africa: Legal perspectives on their protection and promotion (pp. vi-xii). Windhoek, Namibia: Macmillan.

Commonwealth. (2013). Report of the Commonwealth Secretary General 2011-2013. Retrieved from http://thecommonwealth.org/sites/default/files/page/documents/Report\%20of\%20the \%20Commonwealth\%20Secretary-General\%202011-2013\%20Low\%20Res.pdf

Concise Oxford English Dictionary (11th ed.). (2004). Oxford, UK: Oxford University Press.

Coombs, P. H., \& Ahmed, M. (1974). Attacking rural poverty: How non-formal education can help. Baltimore, MD: John Hopkins University Press. 
Dahal, D. R. (2002). Civic education: The problems and possibilities of a democratic life in Nepal. Paper for the Society for the Promotion of Civic Education in Nepal (SPCE). Retrieved from http://www.nepaldemocracy.org/civic_education/civic_education.PDF

Delanty, G. (2000). Citizenship in a global age: Society, culture and politics. Buckingham, UK: Open University Press.

Delanty, G. (2003). Citizenship as a learning process: Disciplinary citizenship versus cultural citizenship. International Journal of Lifelong Education, 22(6), 597-605.

Dib, C. Z. (1988). Formal, non-formal and informal education: Concept/applicability. Paper presented at the Interamerican Conference on Physics Education, Oaxtepec, Mexico, 1987. Retrieved from http://techne-dib.com.br/downloads/6.pdf

Elechi, O. O. (2004, August). Human rights and the African indigenous justice system. Paper presented at the 18th International Conference of the International Society for the Reform of Criminal Law, Montreal, Canada. Retrieved from http://restorativejustice.org/rj-library/human-rights-and-the-african-indigenousjustice-system/5449/

Endresen, K. (2009). Non-formal citizenship education in Cape Town: Struggling to learn, learning to struggle (Unpublished doctoral dissertation). University of KwaZuluNatal, South Africa.

Fitzpatrick, E. A. (2006). What is civic education? National Municipal Review, 5(2), 278282.

Gauntlett, D. (2011). Making is connecting: The social meaning of creativity from DIY and knitting to youtube and web 2.0. Cambridge, UK: Polity Press.

Government of Kenya. (2007). Kenya national youth policy. Sessional Paper No.3. Nairobi, Kenya: Ministry of Youth Affairs.

Government of Lesotho. (1995). The national youth policy for Lesotho. Lesotho, Maseru: Ministry of Gender and Youth, Sports and Recreation.

Government of Lesotho. (2007). Life skills education Standard 4-7 syllabus. Lesotho, Maseru: Ministry of Education and Training.

Government of Uganda. (2004). The national youth policy. A vision for youth in the 21 st century. Kampala, Uganda: Ministry of Gender, Labour and Social Development.

Hall, T., \& Coffey, A. (2007). Learning selves and citizenship: Gender and youth transitions. Journal of Social Policy, 36(2), 279-296. 
Harber, C., \& Mncube, V. (2012). Education, democracy and development: Does education contribute to democratisation in developing countries? London, UK: Symposium Books.

Human Rights Resource Centre (HRRC). (1999). Raising children with roots, rights \& responsibilities: Celebrating the United Nations Convention on the Rights of the Child. Retrieved from http://www/hrusa.org

Independent Electoral Commission (IEC). (2006). Civic and voter education manual. Training for trainers guide. Maseru, Lesotho: IEC.

Innovations in Civic Participation (ICP) \& Pravah. (2009). Nurturing youth active citizenship in India. Report on a stakeholder consultation. New Delhi, India. Retrieved from http://www.icicp.org/wp-content/uploads/2014/07/Nurturing-Youth-ActiveCitizenship-in-India.pdf

International Federation of Red Cross \& Red Crescent Societies (IFRC). (2011). The value of volunteers: Imagine how many needs would go unanswered without volunteers. Retrieved from http://www.ifrc.org/Global/Publications/volunteers/IFRC-Value-ofvolunteers-report-EN.pdf

Isin, E. F., \& Turner, B. S. (2007). Investigating citizenship: An agenda for citizenship studies. Citizenship Studies, 11(1), 5-17.

Jarvis, P. (2008). Democracy, lifelong learning and the learning society: Active citizenship in a late modern age. London, UK: Routledge.

Kelly, A. V. (1995). Education and democracy: Principles and practices. London, UK: Paul Chapman.

Kelly, K. (2006). From an encounter to text: Collecting data in qualitative research. In M. Terre Blanche, K. Durrheim, \& D. Painter (Eds.), Research in practice: Applied methods for the social sciences (pp. 379-397). Cape Town, South Africa: UCT Press.

Morojele, P. J. (2009). Constructions of gender in the context of free primary education: A multi-site case study of three schools in Lesotho (Unpublished doctoral dissertation). University of KwaZulu-Natal, South Africa.

Ngozwana, N. (2014). Understandings of democracy and citizenship in Lesotho: Implications for civic education (Unpublished doctoral dissertation). University of KwaZuluNatal, South Africa.

Nyamnjoh, F. B. (2002). 'A child is one person's only in the womb': Domestication, agency and subjectivity in the Cameroonian grassfields. In R. Werbner (Ed.), Postcolonial Subjectivities in Africa (pp. 111-138). London, UK: Zed Books. 
OAU. (1981). African (Banjul) charter on human and peoples' rights. Retrieved from http://hrlibrary.umn.edu/instree/z1afchar.htm

Oxfam (2006). Education for global citizenship: A guide for schools. London, UK: Oxfam.

Piattoeva, N. (2005). Citizenship education as an expression of democratization and nation building process in Russia. European Education, 37(3), 38-52.

Preece, J. (2009). Lifelong learning and development: A southern perspective. London, UK: Continuum.

Preece, J., \& Mosweunyane, D. (2004). Perceptions of citizenship responsibility amongst Botswana youth. Gaborone, Botswana: Lightbooks.

Republic of South Africa (RSA) (2009). National youth policy 2009-2014. The Presidency. Retrieved from www.thepresidency.gov.za/file/fid/122

Rule, P., \& John, V. (2011). Your guide to case study research. Pretoria, South Africa: van Schaik.

Sigauke, A. T. (2012). Young people, citizenship and citizenship education in Zimbabwe. International Journal of Educational Development, 32, 214-223.

Thakaso, M. N. (2010). The perceptions of young adults at the National University of Lesotho (NUL) about responsible citizenship: With special reference to HIV/AIDS issues (Unpublished M.Ed. thesis). National University of Lesotho, Lesotho.

UNICEF.CA. (2009). Teaching for children's rights. Rights, wants and needs. Card and Activity Kit. For classrooms and Youth Groups. Retrieved from globalclassroom@unicef.ca

United Nations (UN). (2010). World programme of action for youth (WPAY). Retrieved from www.un.org/esa/socdev/unyin/documents/wpay2010.pdf

United Nations Development Programme. (2014). UNDP youth strategy 2014-2017. Empowered youth, sustainable future. Retrieved from http://www.undp.org/content/undp/en/home/librarypage/democraticgovernance/youthstrategy.html

United Nations Development Programme. (2014a). Human development report: Sustaining human progress: Reducing vulnerabilities and building resilience. New York, NY: UN.

Waghid, Y. (2014). African philosophy of education reconsidered: On being human. London, UK: Routledge. 
Wang, C. C. (1999). Photovoice: A participatory action research strategy applied to women's health. Journal of Women's Health, 8(2), 185-192.

Yuval-Davis, N. (2006). Belonging and the politics of belonging. Patterns of Prejudice, 40(3), 197-214. 